\title{
Identification of Phytoplasma Taxa and Insect Vectors of Peach Yellow Leaf Roll Disease in California
}

\section{L. Blomquist and B. C. Kirkpatrick, Department of Plant Pathology, University of California, Davis 95616}

\begin{abstract}
Blomquist, C. L., and Kirkpatrick, B. C. 2002. Identification of phytoplasma taxa and insect vectors of peach yellow leaf roll disease in California. Plant Dis. 86:759-763.

Two peach diseases in California, western X-disease (WX) and peach yellow leaf roll (PYLR) are caused by two genetically distinct phytoplasmas. Based on symptoms alone, WX and PYLR cannot be reliably distinguished. The objectives of this study were to determine which phytoplasma was causing PYLR disease in peach orchards planted near pear orchards and which phytoplasmas were present in potential insect vectors captured in both peach and pear orchards. Leafhoppers and pear psylla were collected from yellow sticky traps placed in three pear orchards and four peach orchards located in the Sacramento Valley from 1994 to 1996. DNA was extracted from potential vectors and suspect diseased trees, and analyzed for the presence of the WX and PYLR phytoplasmas using strain-specific DNA hybridization or polymerase chain reaction (PCR) assays. The most abundant phytoplasma detected in diseased peach trees was the PYLR phytoplasma. In 1994 and 1995, 10 to 25\% of groups of pear psylla tested positive for the PYLR phytoplasma, while no psylla groups tested positive for the WX phytoplasma. Only one captured leafhopper tested positive for the WX phytoplasma. These results indicate the pear psylla is the primary vector of PYLR in northern California.
\end{abstract}

There are two major phytoplasma diseases of peach trees in California, western $\mathrm{X}$-disease (WX) and peach yellow leaf roll (PYLR). Both WX and PYLR cause a general decline in the trees but differ in symptomatology, speed of disease progression, insect vectors, and distribution throughout the state. WX produces abnormally small, chlorotic leaves that appear tattered and shot-holed by mid-summer (Fig. 1) $(4,11,21)$. PYLR produces normalsize leaves, but they yellow and roll downward by late summer. In PYLR, the leaf midribs and lateral veins also are enlarged (Fig. 1). PYLR is characterized by a more rapid tree decline; the infected tree generally takes 2 to 3 years to die after the onset of symptoms. In contrast, a WX-infected tree will typically live five or more years following infection $(4,11,21)$. However, there can be some overlap in symptoms induced by WX and PYLR. Some trees infected with the WX phytoplasma have swollen leaf midribs characteristic of PYLR (7), and sometimes trees infected with the PYLR phytoplasma show leaf shot-holing, a symptom typically associated with WX.

WX and PYLR also appear to be transmitted by different insect vectors. WX can be transmitted by more than five species of

Corresponding author: B. C. Kirkpatrick
E-mail: bckirkpatrick@ucdavis.edu

Accepted for publication 27 February 2002

Publication no. D-2002-0508-01R

(C) 2002 The American Phytopathological Society leafhoppers (16), whereas there is strong evidence that pear psylla is the major vector of PYLR (15, A. H. Purcell, unpublished data). The source of the PYLRinfected psylla is pear orchards that are adjacent to peach orchards. In late fall, many winterform pear psylla disperse from pear orchards to overwinter in surrounding vegetation including adjacent peach orchards. Pear psylla are found on peach trees only at this time. The incidence of PYLR is highest in peach trees planted next to older pear orchards $(14,15)$. There is usually a gradient of diseased trees observed in affected peach orchards, with the highest percentage of infected peach trees closest to the peach-pear orchard border. The number of newly infected peach trees also correlates with the number of pear psylla caught in the peach orchard the previous year (15), and field-collected pear psylla have been shown to transmit PYLR to peach seedlings (A. H. Purcell, unpublished data). The PYLR phytoplasma that was experimentally transmitted by fieldcollected psylla to peach seedlings was phylogenetically identical to the PYLR phytoplasma found in naturally infected peach trees and to the pear decline (PD) phytoplasma in pear trees (5). Numerous attempts to genetically distinguish the PD and PYLR phytoplasmas have been unsuccessful (5, B. C. Kirkpatrick, unpublished results), indicating the PD and PYLR phytoplasmas are very closely related.

WX is phylogenetically distinct from the PYLR/PD phytoplasma. In fact, the PYLR/PD phytoplasma is more closely related to the apple proliferation phytoplasma found in Europe than to the $\mathrm{X}$ disease phytoplasma found in the United States (12). Specific polymerase chain reaction (PCR) primers are available that can differentiate these two phytoplasmas (20). WX is endemic in several wild Prunus species in California, whereas PYLR/PD was probably introduced into California by the pear psylla, and it is now found commonly in pear orchards in the Sacramento and San Joaquin valleys of California (5). Because symptomatology

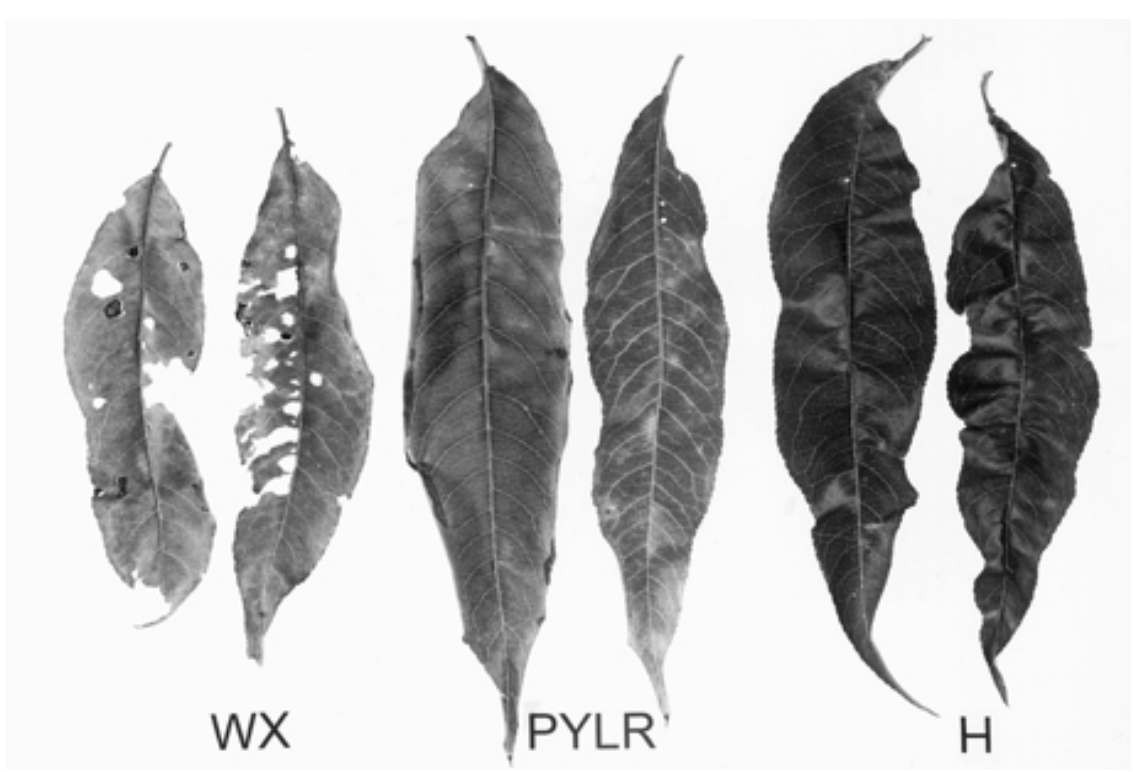

Fig. 1. Peach leaves showing symptoms of western X-disease (WX) or peach yellow leaf roll (PYLR) phytoplasma infection. Healthy leaves for comparison are shown to the far right $(\mathrm{H})$. 
was historically the only way of distinguishing the two peach diseases, and the symptoms can be similar, it is impossible to know exactly when PYLR first occurred in California.

PYLR was first described by Schlocker and Nyland in 1948 (19). The disease occurred primarily in Butte, Placer, Sutter, and Yuba counties, however, trees with symptoms of PYLR were occasionally found in San Joaquin and Stanislaus counties (Table 1). PYLR caused moderate losses in the 1950s and 1960s, killing approximately 4,800 trees. However, the incidence of PYLR increased dramatically in the late 1970 s when a major epidemic killed over 35,000 trees in 1979 alone (14). Since this epidemic, the incidence of PYLR has declined, but it continues to be a chronic problem in the northern California counties of Yuba, Sutter, El Dorado and Placer (Table 1).

The objectives of this study were to find out which phytoplasmas (WX or PYLR) were causing peach yellow leaf roll disease in peach orchards adjacent to pear orchards in northern California, and which phytoplasmas were present in the potential insect vector populations in both pear and peach trees.

\section{MATERIAL AND METHODS}

Orchards and insect collection. Leafhoppers and pear psylla were collected from yellow whitefly sticky traps $(10 \times 16$ $\mathrm{cm}$, Seabright Laboratories, Emeryville, $\mathrm{CA}$ ), hung $1.5 \mathrm{~m}$ from the ground in the tree canopy in three pear orchards and four peach orchards located in Yuba and Sutter counties in the Sacramento Valley from 1994 to 1996 . Ten traps were equally spaced approximately $15 \mathrm{~m}$ apart in peach trees and 10 traps were placed in pear trees at the peach/pear border of each orchard. One of the peach orchards was located across the Yuba River from pear orchards

Table 1. Counties in California where western $\mathrm{X}$-disease and peach yellow leaf roll phytoplasmas have been identified ${ }^{\mathrm{a}}$

\begin{tabular}{lcc}
\hline County & WX $^{\mathbf{b}}$ & PYLR $^{\mathbf{c}}$ \\
\hline Butte & $\mathrm{X}$ & $\mathrm{X}$ \\
Colusa & $\mathrm{X}$ & $\ldots$ \\
Contra Costa & $\mathrm{X}$ & $\ldots$ \\
El Dorado & $\mathrm{X}$ & $\mathrm{X}$ \\
Glenn & $\mathrm{X}$ & $\mathrm{X}$ \\
Los Angeles & $\mathrm{X}$ & $\ldots$ \\
Merced & $\mathrm{X}$ & $\ldots$ \\
Napa & $\mathrm{X}$ & $\ldots$ \\
Placer & $\mathrm{X}$ & $\mathrm{X}$ \\
San Joaquin & $\mathrm{X}$ & $\ldots$ \\
Solano & $\mathrm{X}$ & $\ldots$ \\
Stanislaus & $\mathrm{X}$ & $\ldots$ \\
Sutter & $\mathrm{X}$ & $\mathrm{X}$ \\
Tehama & $\mathrm{X}$ & $\ldots$ \\
Yolo & $\mathrm{X}$ & $\ldots$ \\
Yuba & $\mathrm{X}$ & $\mathrm{X}$ \\
\hline
\end{tabular}

a As reported in A. Schlocker (1957) and B.C. Kirkpatrick, unpublished results.

${ }^{\mathrm{b}}$ Western X-disease.

${ }^{\mathrm{c}}$ Peach yellow leaf roll. so traps were located in peach trees that paralleled the river. The pears across the river were not monitored. Traps were collected and changed biweekly from midMay to the beginning of December. For simplicity, the numbers of insects trapped in two biweekly collections were combined into a monthly count for the population numbers that are presented in Figures 2 and 3. Potential phytoplasma leafhopper and pear psylla vectors were identified, removed from the traps, placed in microfuge tubes, and stored at $-20^{\circ} \mathrm{C}$ until tested for phytoplasmas. Previous work using laboratory-reared WX-infected Colladonus montanus leafhoppers that were placed on yellow sticky traps and hung in an orchard during the summer months, showed that there was only a slight reduction $(5 \%)$ in the number of field-exposed insects that tested positive for the WX phytoplasma by DNA hybridization analysis compared to immediately frozen, WX-infected $C$. montanus (8). The four peach orchards that were monitored for vectors and surveyed for disease contained 512, 880, 1,120, and 1,485 trees. Peach orchards were surveyed annually in September and any potentially symptomatic trees were tested by PCR for PYLR and WX. Pear orchards were monitored only for vectors.

DNA extraction. Total DNA from potential vectors was extracted using the method of Zhang et al. (23) with the following minor modifications: all incubations were for $30 \mathrm{~min}$, and following the isopropanol precipitation of DNA, the nucleic acid pellet from potential leafhopper vectors was suspended in $1 \times \mathrm{TE}, 6 \times$ $\mathrm{SSC}$, denatured at $95^{\circ} \mathrm{C}$ for $8 \mathrm{~min}$, and applied to a reinforced nitrocellulose membrane (Schleicher and Schuell, Keene, $\mathrm{NH}$ ) using a dot blot apparatus (BRL, Bethesda, MD). Potentially diseased trees were tested by extracting DNA from $1 \mathrm{~g}$ of leaf midribs that were processed by a phytoplasma enrichment technique (10); the final nucleic acid pellet was suspended in $50 \mu \mathrm{l}$ of sterile distilled water.

PCR. PCR primers p1/Tint, which are "universal" primers that detect all phytoplasmas tested to date (20), were used to initially screen all peach trees suspected of being infected with a phytoplasma. If a sample tested positive with these universal primers, it was further PCR tested using primers pairs $\mathrm{p} 1 / \mathrm{PYLR}$ and $\mathrm{p} 1 / \mathrm{WX}$ that detect the PYLR and WX phytoplasma (20). Thermocycling parameters for primers $\mathrm{p} 1 / \mathrm{PYLR}$ and $\mathrm{p} 1 / \mathrm{WX}$ were identical to those described by Smart et al. (20). Three microliters (approximately $50 \mathrm{ng}$ ) of peach DNA was used as template in each PCR reaction. Positive and negative controls were DNAs extracted from PYLR- and WX-infected and healthy peach trees that were growing in an experimental orchard at UC Davis. PCR products were electrophoresed in $1 \%$ agarose gels using Trisacetate-EDTA buffer (TAE), stained with ethidium bromide and examined on a UV light box. Samples were considered positive if a DNA fragment of approximately $1.6 \mathrm{~kb}$ was visualized in the gel lane.

DNA hybridization analyses using the PD-specific chromosomal probe, pCPDM10 and the WX-specific probe, wx1. DNA from groups of potential vectors was divided between 2 dot blot manifold wells; one-third placed in the first well and twothirds placed in the second, and applied onto a reinforced nitrocellulose membrane. Membranes were air-dried and then baked at $80^{\circ} \mathrm{C}$ for $1.5 \mathrm{~h}$. Blots were prehybridized in a solution containing $50 \%$ formamide and Denhardt's buffer (17) for at least $2 \mathrm{~h}$ at $42^{\circ} \mathrm{C}$, and then hybridized overnight at $42^{\circ} \mathrm{C}$ in the same buffer with $100 \mathrm{ng}$ random primer-labeled (2) ${ }^{32} \mathrm{P}$-dATP CPDM10 (5, see below) or ${ }^{32}$ P-dATP wx1 (10). The membranes were washed once at room temperature for $30 \mathrm{~min}$ and once for 15 min at $55^{\circ} \mathrm{C}$ in $0.2 \times \mathrm{SSC}$ with $1 \mathrm{~g} /$ liter sodium dodecyl sulfate (SDS). Membranes were exposed to a phosphoimaging screen (Fuji Photo Film Co. Ltd., Tokyo, Japan) for 2 to $3 \mathrm{~h}$. Signal strength was measured on the BAS 1000 phosphoimaging system (Fuji Photo Film Co., Ltd.) and analyzed using MacBAS 2.0 software (Fuji Photo Film Co. Ltd.). Insect samples were considered to be positive if they had a signal strength that was at least two times background. Following hybridization with PYLR specific probes, blots were stripped by washing 3 times in $0.1 \times \mathrm{SSPE}, 5 \mathrm{~g} /$ liter SDS $95^{\circ} \mathrm{C}$ for $10 \mathrm{~min}$. Membranes were exposed to the phosphoimaging screen for several hours to determine residual background counts, before being hybridized with the ${ }^{32} \mathrm{P}$-labeled WX-specific chromosomal probe, wx1.

CPD-M10 is a cloned 1.6-kb fragment of the PD chromosome that does not hybridize with any other phytoplasma present in California (5). CPD-M10 was obtained by PCR amplification using primers fCPD and $\mathrm{rCPD}(5,13)$, PD-infected pear DNA as a template, and the resulting $1.6-\mathrm{kb}$ PCR product was cloned into a TA plasmid vector (Invitrogen, Carlsbad, CA). pCPD-M10 was digested with EcoRI to release the cloned fragment of PD DNA, and the insert (CPD-M10) was gel-purified (Prep-AGene, BioRad, Hercules, CA). CPD-M10 DNA was quantified using the TKO 100 minifluorometer (Hoefer Scientific, San Francisco, CA) according to the manufacturer's instructions before being used as a positive control or labeled with ${ }^{32} \mathrm{P}$ by random primer labeling (2).

\section{RESULTS}

The identity and quantity of leafhoppers trapped varied in both pear and peach orchards and over time (Table 2). Identified leafhoppers were from groups that are known to be primarily mesophyll, phloem, or xylem feeders (Table 2). Edwardsiella and Empoasca spp. (mesophyll feeders) 
were caught in large numbers on the traps, and are recorded as a composite value in Table 2. Approximately 400 of these mesophyll feeders were analyzed in groups of 10 over the course of this study, and in all cases they tested negative for the WX and PYLR phytoplasma. Because phytoplasmas are known to be phloem-limited, we concentrated our analysis on the leafhoppers that are phloem feeders, and are known to transmit the WX phytoplasma and the aster yellows phytoplasma, although other phloem feeders were also analyzed (data not shown). Among these leafhoppers, more Paraphlepsius spp. were trapped in pear (201) than peach (84), and more Macrosteles spp. were trapped in peach (204) than pear (80). However, because of the large variation in the number of leafhoppers trapped between orchards, no obvious trends were identified (Fig. 2A and 2B). In general, leafhopper populations were greater in the spring and fall than in mid-summer, except for Macrosteles spp. whose population peaked in mid-summer.
Among the phloem-feeding leafhoppers tested by hybridization for phytoplasmas, only one group of Paraphlepsius spp. collected in a pear orchard tested positive for $\mathrm{WX}$, and one other group also collected in pear, tested positive for the PYLR/PD phytoplasma (Table 3).

Pear psylla (Fig. 3A and 3B) numbers remained low until August when they increased in pear, and somewhat later, in peach. Pear psylla numbers were low in 1995 and 1996 compared to 1994. In 1994 and 1995 , between 1 in 4 to 1 in 10 groups of pear psylla tested positive for the PYLR/PD phytoplasma (Table 3). In 1994 and 1995, PYLR/PD phytoplasma-infected psylla was trapped both in peach and pear from all orchard sites. In 1996, no phytoplasma-infected psylla were detected. These results suggest that pear psylla are the most abundant PYLR/PD vectors present in these orchards.

The most abundant phytoplasma detected in peach trees with symptoms of WX or PYLR was the PYLR/PD phytoplasma.

Table 2. Leafhoppers captured on yellow sticky traps in pear and peach orchards from 1994 to 1996

\begin{tabular}{|c|c|c|c|c|c|c|}
\hline \multirow[b]{2}{*}{ Genus/Family } & \multicolumn{2}{|c|}{1994} & \multicolumn{2}{|c|}{1995} & \multicolumn{2}{|c|}{1996} \\
\hline & Peach & Pear & Peach & Pear & Peach & Pear \\
\hline Colladonus spp. & 7 & 1 & 17 & 2 & 24 & 20 \\
\hline Paraphlepsius spp. & 7 & 12 & 35 & 65 & 42 & 124 \\
\hline Fieberiella florii & 14 & 22 & 3 & 3 & 11 & 6 \\
\hline $\begin{array}{l}\text { Edwarsiella and Empo- } \\
\text { sasca } \text { spp. }\end{array}$ & 2,276 & 2,473 & 3,746 & 5,373 & 1,782 & 4,945 \\
\hline Sharpshooters ${ }^{\mathrm{a}}$ & 69 & 2 & 30 & 10 & 17 & 6 \\
\hline Amblysellus spp. & 25 & 1 & 86 & 31 & 133 & 79 \\
\hline Exitianus spp. & 17 & 0 & 6 & 2 & 18 & 18 \\
\hline Macrosteles spp. & $n d^{b}$ & nd & 109 & 54 & 95 & 26 \\
\hline Idiocerinae & nd & nd & 17 & 12 & 19 & 8 \\
\hline Unclassified & 163 & 46 & 130 & 39 & 66 & 24 \\
\hline
\end{tabular}

a Draeculacephala minerva and Carneocephala fulgida.

${ }^{\mathrm{b}}$ Species not determined.

Table 3. Western-X infected insects and peach yellow/pear decline leaf roll-infected insects from $1994-1996^{\mathrm{a}}$

\begin{tabular}{|c|c|c|c|c|c|c|}
\hline \multirow[b]{2}{*}{ Name (spp.) } & \multicolumn{2}{|c|}{1994} & \multicolumn{2}{|c|}{1995} & \multicolumn{2}{|c|}{1996} \\
\hline & Peach & Pear & Peach & Pear & Peach & Pear \\
\hline \multicolumn{7}{|c|}{ Western- $X$ infected insects $b$} \\
\hline Cacopsylla pyricola ${ }^{\mathrm{c}}$ & $0 / 46^{d}$ & $0 / 189$ & $0 / 10$ & $0 / 100$ & $0 / 4$ & $0 / 46$ \\
\hline Colladonus spp. ${ }^{\mathrm{e}}$ & $0 / 3$ & $0 / 1$ & $0 / 6$ & $0 / 3$ & $0 / 16$ & $0 / 19$ \\
\hline Fieberiella florii $^{\mathrm{e}}$ & $0 / 2$ & $0 / 12$ & $0 / 1$ & $0 / 3$ & $0 / 9$ & $0 / 6$ \\
\hline Macrosteles spp. ${ }^{\mathrm{e}}$ & $0 / 0$ & $0 / 0$ & $0 / 41$ & $0 / 12$ & $0 / 43$ & $0 / 9$ \\
\hline Paraphlepsius spp. ${ }^{\mathrm{e}}$ & $0 / 0$ & $0 / 2$ & $0 / 7$ & $0 / 42$ & $0 / 38$ & $1 / 94$ \\
\hline \multicolumn{7}{|c|}{$\begin{array}{l}\text { Peach yellow/pear decline leaf roll-infected } \\
\text { insects }^{f}\end{array}$} \\
\hline Cacopsylla pyricola ${ }^{\mathrm{c}}$ & $10 / 46^{\mathrm{d}}$ & $65 / 189$ & $1 / 10$ & $9 / 100$ & $0 / 4$ & $0 / 46$ \\
\hline Colladonus spp. ${ }^{\mathrm{e}}$ & $0 / 3$ & $0 / 3$ & $0 / 6$ & $0 / 3$ & $0 / 16$ & $0 / 19$ \\
\hline Fieberiella florii $^{\mathrm{e}}$ & $0 / 2$ & $0 / 12$ & $0 / 1$ & $0 / 3$ & $0 / 9$ & $0 / 6$ \\
\hline Macrosteles spp. ${ }^{\mathrm{e}}$ & $0 / 0$ & $0 / 0$ & $0 / 41$ & $0 / 12$ & $0 / 43$ & $0 / 9$ \\
\hline Paraphlepsius spp. ${ }^{\mathrm{e}}$ & $0 / 0$ & $0 / 2$ & $0 / 7$ & $0 / 42$ & $0 / 38$ & $1 / 94$ \\
\hline
\end{tabular}

a Insects were caught on yellow sticky traps hung every 2 weeks between mid-May and the beginning of December.

${ }^{b}$ DNA was extracted from the insects and assayed by DNA hybridization using a ${ }^{32} \mathrm{P}-$ labeled WXspecific hybridization probe.

${ }^{c}$ Psylla were generally analyzed in groups of ten. If fewer than ten were caught at a particular site in a 2-week period, that number was assayed as a group (1-9).

${ }^{\mathrm{d}}$ Fraction $=$ number of hybridization positive/number tested.

${ }^{\mathrm{e}}$ Leafhoppers were analyzed individually or in pools of up to three individuals.

${ }^{\mathrm{f}}$ DNA was extracted from the insects and assayed by DNA hybridization using a PYLR/PD specific hybridization probe.
Only two of the peach trees sampled were infected with the WX phytoplasma whereas 105 were infected with the PYLR phytoplasma (Table 4). The two WX-infected peach trees were found in different orchards in 1994 and 1996. These results show that where pear is grown next to peach, the PD/PYLR phytoplasma is the most common phytoplasma found in symptomatic peach trees in the Sacramento Valley.

\section{DISCUSSION}

The numbers of pear psylla, both collected and infected with the PYLR phytoplasma were low in 1995 and 1996 because growers began controlling psylla these years with more effective insecticides.

Only two of the groups of Paraphlepsius spp. leafhoppers, both collected in pear orchards, tested positive for phytoplasmas. This was an unexpected result with regards to the incidence of the WX phytoplasma considering that approximately $3 \%$ of $\mathrm{Col}$ ladonus spp., Fieberiella florii, and Paraphlepius spp. leafhoppers collected in a sweet cherry growing district located approximately $320 \mathrm{~km}$ south of this study area tested positive for the WX phytoplasma using the same wx1 hybridization probe in the late $1980 \mathrm{~s}(8, \mathrm{~B}$. C. Kirkpatrick, unpublished data). The current absence of high titer reservoirs of WX such as sweet cherry and other wild Prunus hosts near the peach orchards in the Sac-

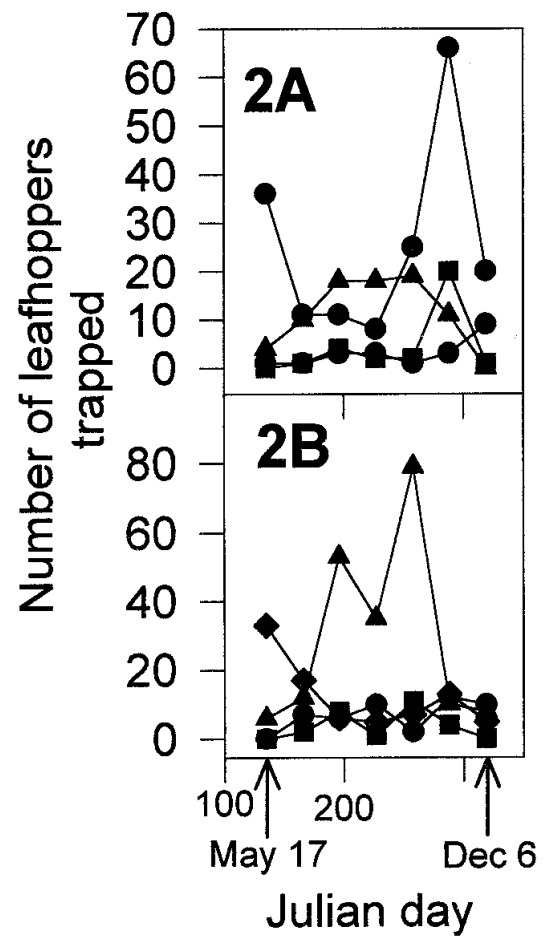

Fig. 2. Total numbers of potential leafhopper vectors trapped in $\mathbf{A}$, peach and $\mathbf{B}$, pear from mid-May to the beginning of December from 1994 to 1996 . Two biweekly collections were combined for each data point. $\mathbf{\square}=$ Colladonus spp., $\quad=$ Macrosteles spp., $\mathbf{\Delta}=$ Para phlepsius spp. 
ramento Valley may explain why only one group of leafhoppers tested positive for WX. It is unclear whether the one group of Paraphlepsius leafhoppers that tested positive for PYLR represents a truly systemically infected insect, or a gut-limited infection. No other information obtained from this study or others suggest that Paraphlepsius spp. can transmit the PYLR/PD phytoplasma. In contrast to the leafhopper results, many groups of psylla were infected with the PYLR/PD phytoplasma, which supports other studies suggesting pear psylla is probably the primary vector of PYLR $(14,15$, A. H. Purcell, unpublished results). These results are also consistent with other studies that have demonstrated that psylla are the primary vectors of phytoplasmas found in the apple proliferation phylogenetic clade. Carraro et al. (1) showed that Cacopsylla pruni transmitted the European stone fruit yellows phytoplasma, and Frisinghelli et al. (3) showed that Cacopsylla costalis transmitted an Italian strain of the apple proliferation phytoplasma. It is noteworthy, that the results of phylogenetic studies on phytoplasmas provided the impetus for several of the vector transmission studies that ultimately determined that various psylla species, and not leafhoppers, were the primary insect vectors of phytoplasmas comprising the apple proliferation/pear decline phylogenetic clade.

We specifically chose to assess the potential infectivity of field-collected vectors

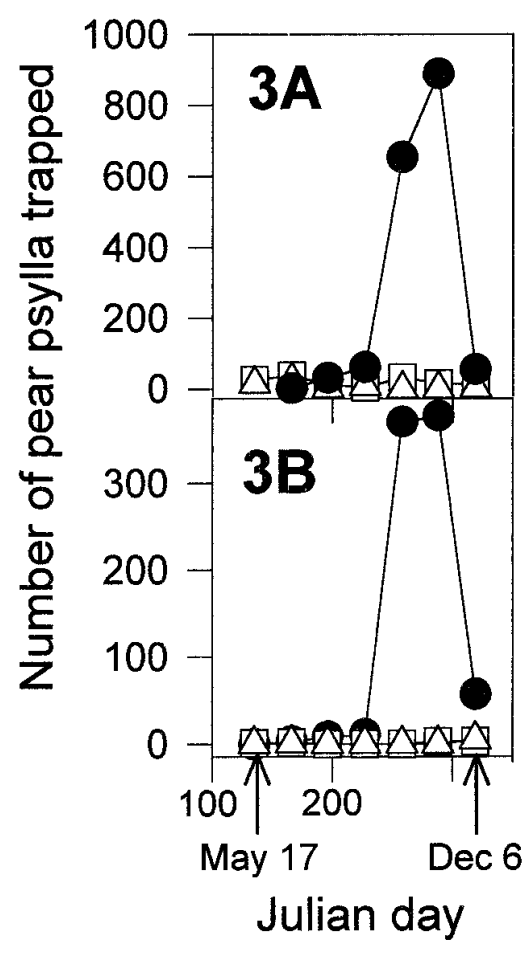

Fig. 3. Pear psylla trapped in pear and peach from mid-May to the beginning of December from 1994 to 1996. More effective insecticides were used to control pear psylla in 1995 and 1996. $=1994, \Delta=1995, \square=1996$. using DNA hybridization assays rather than PCR for two reasons. Larger numbers of insect samples can be more readily examined by hybridization assays than by individual PCR reactions. DNA hybridization readily detects phytoplasma DNA in infected vectors $(8,10)$, and it does not have the problem of producing potential positive test results for nonvector insects that simply fed on a phytoplasma-infected plant (B. C. Kirkpatrick, unpublished data); a complication that may limit the interpretation of positive test results obtained by PCR (22). In a parallel study that assessed the seasonal infectivity of the pear decline phytoplasma in pear psylla, we found a good correlation between results obtained by DNA hybridization and PCR, with PCR detecting PD phytoplasmas in approximately twice (13.8 versus $6.4 \%$ ) as many PD-infected pear psylla (C. L. Blomquist, unpublished data). Thus, we felt that DNA hybridization assays were the best tool to rapidly screen large numbers of diverse, potential insect vectors, and that positively testing species were likely to be systemically infected with the phytoplasma in question.

In the 1950s, Schlocker (18) reported that at least $25 \%$ of peach trees with symptoms of phytoplasma infection in Yuba, Sutter, and Butte counties had symptoms of WX. The results from this study show that the percentage of symptomatic trees with WX has changed, at least in the four representative peach orchards that were surveyed. However, it must be emphasized that the previous surveys were based on symptoms that are much less definitive than pathogen-specific diagnostic assays used in this study. Today, in these counties, there are fewer wild Prunus hosts that could act as reservoirs for WX. We do not know what served as a reservoir for WX in the 1950s, but perhaps there was a larger wild Prunus population at that time. The most common crops currently grown in the area are walnuts, peaches, pears, and French prune (Prunus domestica). Of these crops, only peaches are susceptible to WX, and peaches have been shown to be a poor vector acquisition host of the WX phytoplasma $(4,6)$. A previous report detected WX in pear by enzyme-linked immunosorbent assay (ELISA) (9), but these results were never repeated using DNA hybridization (B. C. Kirkpatrick, unpublished results) or PCR (5). The current absence of an efficient reservoir for WX is the most likely explanation for the low levels of WX in the peach trees and leafhoppers sampled from this area of California. However, as previously noted, the typical foliar symptoms of WX-infected peaches, especially late-season shot-holing, can sometimes be produced by the PYLR/PD phytoplasma. Thus, some of the trees reported by Schlocker (18) to be infected with WX may have been actually infected with the PYLR/PD phytoplasma.

The PYLR phytoplasma was found to be the primary phytoplasma infecting peach trees in the four orchards that were surveyed in Yuba and Sutter counties. The primary vector, pear psylla, is now controlled in winter by dormant oil sprays, in early summer and fall with new, very effective insecticides, such as Agri-Mek (Syngenta Corp., Basel, Switzerland), and in mid-summer by the Sacramento Valley's hot temperatures. Fall insecticidal sprays were typically not applied after fruit harvest in the 1970s and 1980s, so psylla populations increased dramatically in the fall. In the 1980s, pear psylla, which is slightly larger than an aphid, was so numerous in peaches they "produced a rustling sound audible from 15 to $20 \mathrm{~m}$ away" (15). In transmission studies performed in the 1980s, one of eight healthy trees that were exposed to 10,000 field-collected psylla per tree developed symptoms of peach yellow leaf (A. H. Purcell, unpublished results). This apparently inefficient transmission of PYLR is also consistent with field observations; if psylla transmission was more efficient, there would be no healthy peach trees in orchards near pear plantings. Because hundreds or even thousands of pear psylla appear to be necessary for transmission of the PD/PYLR phytoplasma to peach, the transmission of PYLR by pear psylla must be a comparatively rare event. It is unclear whether there is a subpopulation of the PD/PYLR phytoplasmas in pear trees that is capable of multiplying in peach trees, or there are strict phenological parameters in the peach tree that determine whether a peach yellow leaf roll infection survives the winter. However, there are numerous plantings of peaches near pears in many areas around the world, yet PYLR appears to be found only in California. This distribution suggests there is a unique sub-strain of the PD-phytoplasma in California that has evolved the ability to multiply and cause disease in peach.

Table 4. Peach trees tested for phytoplasmas from 1994 to 1997

\begin{tabular}{lccccl}
\hline Year & Trees tested & PCR+a & PCR- & PYLR $^{\mathbf{b}}$ & $\mathbf{W X}^{\mathbf{c}}$ \\
\hline 1994 & 92 & 33 & 59 & $32 / 33$ & $1 / 33$ \\
1995 & 47 & 9 & 38 & $9 / 9$ & $0 / 9$ \\
1996 & 64 & 22 & 42 & $21 / 22$ & $1 / 22$ \\
1997 & 80 & 43 & 37 & $43 / 43$ & $0 / 43$ \\
\hline
\end{tabular}

a PCR positive by the general phytoplasma primer pair p1/Tint.

${ }^{b}$ PCR positive by peach yellow leaf roll-specific primers.

c PCR positive by western-X-specific primers. 
Based on the information obtained in this and previous studies $(14,15$; A. H. Purcell, unpublished data), pear growers are now aware that pears are the primary reservoir for PYLR in northern California. Their subsequent use of highly effective insecticides to control late season populations of pear psylla, which had previously migrated out of pear and into adjacent peach orchards, has greatly reduced the incidence to PYLR in the last 8 years.

\section{ACKNOWLEDGMENTS}

This work was supported in part by the University of California IPM program and the California Cling Peach Advisory Board.

\section{LITERATURE CITED}

1. Carraro, L., Osler, R., Loi, N., Ermacora, P., Refatti, E. 1998. Transmission of European stone fruit yellows phytoplasma by Cacopsylla pruni. J. Plant Pathol. 80:233-239.

2. Feinberg, A. P., and Vogelstein, B. 1983. A technique for radiolabeling DNA restriction endonuclease fragments to high specific activity. Anal. Biochem. 132:6-13.

3. Frisinghelli, C., Delaiti, L., Grando, M. S., Forti, D., and Vindimian, M. E., 2000. Cacopsylla costalis (Flor 1861), as a vector of apple proliferation in Trentino. J. Phytopathol. 148:425-431.

4. Gilmer, R. M., Palmiter, D. H., Schaefers, G. A., and McEwen, F. L. 1966. Leafhopper transmission of X-disease virus of stone fruits in New York. New York State Agric. Exp. Stn. Bull. 813:1-22.

5. Guerra, L. J. 1997. Biological and Molecular Characterization of Phytoplasmas Infecting Fruit and Nut Trees in California, Ph.D. thesis, University of California, Davis.

6. Jensen, D. D. 1957. Differential transmission of peach yellow leaf roll virus to peach and celery by the leafhopper, Collodonus montanus. Phytopathology 47:575-578.

7. Jensen, D. D., Frazier, N. W., and Thomas, H. E. 1952. Insect transmission of yellow leaf roll virus of peach. J. Econ. Entomol. 45:335337.

8. Kirkpatrick, B. C., Fisher, G. A., Fraser, J. D., and Purcell, A. H. 1990. Epidemiological and phylogenetic studies on western X-disease mycoplasma-like organisms. Pages 288-296 in: Recent Advances in Mycoplasmology, G. Stanek, G. H. Cassell, J. G. Tully, and R. F. Whitcomb, eds. Gustav Fisher Verlag, New York.

9. Kirkpatrick, B. C., Purcell, A. H., Gao, J. L., Fisher, G. F., and Uyemoto, J. K. 1993. At least three genetically distinct MLOs cause pear decline and peach yellow leaf roll disease in California. Phytopathology 83:1341.

10. Kirkpatrick, B. C., Stenger, D. C., Morris, T. J., and Purcell, A. H. 1987. Cloning and detection of DNA from a nonculturable plant pathogenic mycoplasma-like organism. Science 238:197-200.

11. Kirkpatrick, B. C., Uyemoto, J. K., and Purcell, A. H. 1995. X-disease. Pages 58-59 in: Compendium of Stone Fruit Diseases, J. M. Ogawa, ed., American Phytopathological Society, St. Paul, MN.

12. Kison, H., Kirkpatrick, B. C., and Seemüller, E. 1997. Genetic comparisons of the peach yellow leaf roll agent with European fruit tree phytoplasmas of the apple proliferation group. Plant Pathol. 46:538-544.

13. Lorenz, K. H., Schneider, B., Ahrens, U., and Seemuller, E. 1995. Detection of the apple proliferation and pear decline phytoplasmas by PCR amplification of ribosomal and nonribosomal DNA. Phytopathology 85:771-776.

14. Purcell, A. H., Nyland, G., Raju, B. C., and Heringer, M. R. 1981. Peach yellow leaf roll epidemic in northern California: effects of peach cultivar, tree age, and proximity to pear orchards. Plant Dis. 65:365-368.

15. Purcell, A. H., and Suslow, K. G. 1984. Surveys of leafhoppers (Homoptera: Cicadellidae) and pear psylla (Homoptera: Psyllidae) in pear and peach orchards and the spread of peach yellow leaf roll disease. J. Econ. Entomol. 77:1489-1494.

16. Rice, R. E., and Jones, R. A. 1972. Leafhopper vectors and the western X-disease pathogen: collections in California. Environ. Entomol. 1:726-730.

17. Sambrook, J., Fritsch, E. F., and Maniatis, T. 1989. Molecular Cloning: A Laboratory Manual 2nd ed, Cold Spring Harbor Laboratory, Cold Spring Harbor, NY.

18. Schlocker, A. 1957. Peach yellow leaf roll and western X-disease of peach. Calif. Dep. Agric. Bull. 16:173-176.

19. Schlocker, A., and Nyland, G. 1951. Yellow leaf roll of peach. Calif. Dep. Agric. Bull. 15:39-42.

20. Smart, C. D., Schneider, B., Blomquist, C. L. Guerra, L. J., Harrison, N. A., Ahrens, U., Lorenz, K. H., Seemüller, E., and Kirkpatrick, B. C. 1996. Phytoplasma-specific PCR primers based on sequences of the 16S-23S rRNA spacer region. Appl. Environ. Microbiol. 62:2988-2993.

21. Teviotdale, B., Ogawa, J. M., Nyland, G., and Kirkpatrick, B. C. 1989. Pages 118-132 in: Diseases. Peaches, Plums and Nectarines. J. H. LaRue and R. S. Johnson, eds. University of California, Division of Natural Resources, Oakland. Publ. 3331.

22. Vega, F. E., Davis, R. E., Barbosa, P., Dally, E. L., Purcell, A. H., Lee, I.-M., 1993. Detection of a plant pathogen in a nonvector insect species by the polymerase chain reaction. Phytopathology 83:621-624.

23. Zhang, Y.-P., Uyemoto, J. K., and Kirkpatrick, B. C. 1998. A small-scale procedure for extracting nucleic acids from woody plants infected with various phytopathogens for PCR assay. J. Virol. Methods 71:45-50. 